\title{
Gamification in Ride-Hailing: What Drives a Driver to Drive
}

\author{
Taofik Hidajat \\ Management Study Program \\ School of Economics and Business \\ (STIE) of Bank BPD Jateng \\ Semarang, Indonesia \\ inidotcom@yahoo.com
}

\author{
Agung Hendra Kusuma \\ Accounting Study Program \\ School of Economics and Business \\ (STIE) of Bank BPD Jateng \\ Semarang, Indonesia \\ hendragung07@gmail.com
}

\author{
Achmad Sulchan \\ Faculty of Law \\ Sultan Agung Islamic University \\ Semarang, Indonesia \\ ach.sulchan@unissula.ac.id
}

\begin{abstract}
This paper discusses whether there is gamification in ride-hailing drivers in Indonesia. Using qualitative research methods it shows that the driver experiences illusionary freedom. Through technology, drivers experience this illusion of freedom through gamification. An interesting finding is that drivers cheat to chase targets, especially during a pandemic. Competition between drivers and the desire to get a bonus makes them have to work hard and compete with each other to get passengers, including by committing fraud. Even though they are considered as partners, the driver's position is inferior to the company. The regulations governing partnership relations are urgent to be issued.
\end{abstract}

Keywords: gamification, ride-hailing, transportation network companies, Grab, Go-Jek, Indonesia

\section{INTRODUCTION}

Grab and Go-Jek are the transportation network companies (TNCs) that have dominated the ride-hailing business in Indonesia since Uber left the online transportation business. They are growing fast in a vast market. However, their business growth is also overshadowed by various problems. One of the issues that attracted the most attention was the relationship between TNCs and the driver. The position of the driver as a partner creates vulnerability in the form of exploitation through gamification. Is it true that exploitation through gamification occurs in ride-hailing drivers?

Online transportation services have existed in Indonesia since 2010 but have grown since Go-Jek (2015) has joined the market and has become a general transportation application. The services provided are also increasingly diverse. They provide not only pick-up but also other services such as delivering food and goods, massages, cleaning the house and so on. Apart from Grab and Go-Jek, there are more than twenty online transportation applications on Google Playstore and other ride-hailing services that serve local markets such as Greenjek (Karawang), Ko-Jek (Kalimantan), Si-Jek (Situbondo), Pas-Jek (Sampit), and so on.

Statista noted that online transportation revenue in Indonesia reached the US $\$ 3.63$ billion or IDR 50.4 trillion per year. The survey results from the UI Demographic Institute (2018) concluded that Go-Jek has a positive effect on the economy. The income contribution of the four largest
Go-jek service partners (GoRide, GoCar, GoFood, and GoLife) reached IDR 44.2 trillion.

Although it has had a positive impact, some research shows that the online transportation business still faces problems such as incomplete regulations (Dyah, 2019; Wahyuningtyas, 2019) and the partnership relationship between drivers and TNCs (Nastiti, 2017). This partnership problem is interesting to study because there is no bond between the driver and the TNCs. Drivers are partners, not employees. This relationship pattern is prone to injustice. Moreover, TNCs will only give bonuses if the driver can meet the target. To achieve this target, the driver must work hard.

Nastiti (2017) states that there is an exploitation of GoJek drivers through the use of applications. Also, using a daily point and target system to get incentives is a form of gamification. Mason (2018), who researched Lyft and Uber drivers, stated that through technology, TNCs carried out gamification.

This article wants to see if there is gamification in ridehailing drivers in Indonesia. To our knowledge, there has been no research that qualitatively examines this problem. This research is essential for two reasons, namely 1) this theme has received very little attention, and 2) the profession as a ride-hailing driver is starting to be the choice of the younger generation.

An assessment of the relationship between TNCs and drivers is necessary to help illustrate the real relationship. Thus, it will be known whether the driver gets the equivalent returns or only becomes an exploited worker through the application platform.

\section{METHODOLOGY}

This research uses a qualitative research approach and a case study methodology through interviews with Grab and Go-Jek ride-hailing drivers.

A qualitative approach and case study methodology are the most reasonable ways to assess aspects of business behaviour and culture (Eisenhardt, 1989). Qualitative methods are a way to understand complex phenomena (Birkinshaw et al., 2011). We think that Grab and Go-Jek are complex phenomena because they involve platforms, new habits, partnerships and regulations.

To obtain data, we become passengers who order pickup services via applications to various locations in 
Semarang, Yogyakarta and Jakarta. While in the car or riding on the motorbike, we offer anonymous interviews and explain the purpose of the research. If the driver agrees, we conduct an interview (chat) using a tape recorder.

Twenty-five drivers were interviewed and agreed to give their opinion. Questions to the driver are about work motivation, full time or part-time status, results received, interactions between drivers and the partnership relationship.

\section{RESULTS AND DISCUSSION}

\subsection{Illusionary freedom, gamification and fraud}

Grab and Go-Jek initially adopted the Uber technologies taxi service model. They then revolutionized business services to meet local needs and grew along with traffic problems that occurred in major cities in Indonesia. Vehicle congestion, traffic jams and unscheduled modes of transportation are some of the things that make road users choose online transportation.

Great user demand makes many people join as drivers. The results of this study indicate that most of the drivers of productive age make ride-hailing their primary job. Sixty per cent of drivers choose to work full time because they have no other job. Being a driver is the only way to earn money. This result is following the study of Rakhmatulloh et al., (2018) and the UI Demographic Institute (2018) that ride-hailing drivers are dominated by young people who want to earn income with flexible working time.

Interestingly, forty per cent of drivers previously had jobs but then chose to quit and become ride-hailing drivers. At first, they were attracted by the flexibility of working time. Some of them even dare to take debt to buy a new vehicle. Part of the money earned from work is used to pay off these debts. For those who choose to be a part-time driver, the motivation to work is to get extra money. They work without targets and burdens. For those who choose a part-time, money is not a problem.

However, recently, the revenue from driving has not been as large as the early days of ride-hailing services. When the start of this service appeared, drivers could earn much money. After that, the commission for the driver is reduced. Fuel prices have also risen. Competition between drivers for passengers is also getting tighter.

Drivers have to work hard to earn money and bonuses. To earn bonuses or extra cash, drivers must exceed the target, something almost all drivers find challenging to do. They also told of the dishonest behaviour of drivers who manipulated for profit due to increasingly fierce competition.

Berliner \& Tal (2018) who researched Lyft and Uber drivers also stated that the biggest motivation for someone to become a driver is because they want to get much money. Apart from getting extra money, this job is also attractive because it offers flexibility (Robert, 2019). Uber promises "flexible employment" because drivers can enter and leave work at any time. The flexibility of working hours encourages young workers to remain as driverpartners and keep driving.

In some ways, the flexibility for the driver is correct. Unlike employees who work in offices or factories, ridehailing drivers have flexible hours and workplaces. Drivers are free to join, work and quit anytime. However, Robert (2019), who researched Uber drivers in Paris, stated that drivers experience "illusionary freedom", a condition where they feel they experience the freedom of work. It is as if the drivers experience freedom, but in fact, they experience exploitation. Rosenblat \& Stark (2016) who looked at the work of Uber drivers for nine months, concluded that the company's promises regarding freedom, flexibility, and entrepreneurship were contradicting what happened. Most Lyft and Uber drivers in Colorado earn less than the minimum wage (Henao \& Marshall, 2019).

Mason (2018), who researched Lyft and Uber drivers, stated that through technology, the company manages the illusion of freedom subtly by performing gamification. When ranked highly, drivers are motivated to drive. When they are ranked low, drivers are also more motivated to drive.

The use of "games" in work was discovered by Burawoy (1985). Burawoy (1985) who was curious about why workers in a company worked so hard, found the answer that this happened because of "the game". The company makes a "mission" work to be completed like a game, and workers will do whatever it takes to complete the mission. After a mission is completed, a new mission will be created, and so on. He also found something interesting that when work takes the form of a game, the conflict that occurs is no longer between the worker and the boss, but with fellow workers. It is just like in a strategy game: players must compete with each other to win missions.

Apart from making drivers work harder, gamification can also be used for worker retention (Mason, 2018). Drivers who miss their target or get low ratings can easily be replaced by someone else. A report from the Institute of Transportation Studies at the University of California shows that only $4 \%$ of drivers made it to the target (Berliner \& Tal, 2018).

The increasing number of drivers and the desire for bonuses make them have to work hard and compete with each other for passengers. So, naughty drivers do various ways to get passengers and meet targets, including by committing fraud. The fraud that many drivers do is through a fake global positioning system (GPS) and fake orders.

The use of this application on ride-hailing is done to confuse the system by manipulating GPS location (Zeng et al., 2017). This method is done to get orders even though the driver's position is far from the potential passenger. By opening root access or jailbreaking your smartphone, fake GPS will provide information as if the driver's position is close to the passenger. This method is detrimental to other drivers and passengers. Other drivers lost orders because they were taken by fake GPS user drivers and were further 
away from the passengers, and passengers had to wait for the driver to arrive longer.

Using two different smartphones, the driver will act as a potential passenger and ask himself for pick-up orders. They will set orders close to the driver's position. If this request is successful, the driver will receive the order and appear to have escorted the passenger. If the request fails because another driver received an order, they will cancel the order.

The Institute for Development of Economics and Finance (Indef) survey of 516 online driver-partners in 2018 stated that $61 \%$ of drivers knew that their partner was cheating. More than eighty per cent of drivers have been victims of fictitious orders.

\subsection{Weaknesses of regulation}

One of the variables that must be included in discussing ride-hailing issues is regulation. Regulations generally run more slowly than technological developments and business practices, such as what happens in online transportation. It is indicated by the problems that arise when the business platform is running.

When this condition occurs, the choice of regulators is to make regulations, make threats or do nothing (Brito, 2014). Wyman (2017) argues that online taxis and traditional taxis are substitutes so that regulators should set regulatory standards. However, the presence of TNCs in almost all countries is not classified as a transportation business, as is the case in the USA (Gavin, 2017; Nurhidayah \& Alkarim, 2017). Companies in the ondemand economy usually use their identity and regulations as platform and technology companies (Tartelton, 2010). For example, Uber is categorized as an informationsharing-technology company in San Francisco.

In the United States, TNC was able to convince the court that they were an information technology company, not a transportation company. Therefore, all regulations for taxi companies should not be applied to TNC. However, TNC, which is based in Indonesia, has not found a solution (Nurhidayah \& Alkarim, 2017). As a result, transportation sector regulations cannot be applied to TNCs. All regulations for conventional taxi companies should not apply to TNC. Unlike TNCs, conventional taxis must comply with many regulations. Conventional taxis cannot freely raise rates while TNCs are free to do so.

In Indonesia, regulators are also late in regulating disrupted sectors such as peer to peer lending (Hidajat, 2019), digital payments and online transportation. As a result, markets take the initiative to self-regulate themselves (self-regulation). Wahyuningtyas (2019) who conducted a case study on Go-Jek found that regulators were late in regulating the existence of online transportation so that this company can regulate itself by playing a role both as an intermediary and an infomediary. According to Dyah (2019), the response of the governments of Indonesia, the
Philippines and Taiwan to online transportation is incremental and trial-error.

The unclear regulations regarding the partnership relationship between the driver and TNCs mean that ridehailing drivers cannot claim their rights according to the labour law. Even though the driver is considered a partner, in reality, the TNCs are in a position of superiority.

\section{CONCLUSION}

Extra cash and working time flexibility are two factors that attract a person to become a ride-hailing driver. However, over time, these two factors are an illusion. Drivers find it increasingly difficult to find passengers and money due to increased competition and reduced fares.

Through gamification, drivers are encouraged to keep getting orders. This difficulty caused some drivers to cheat through a fake global positioning system (GPS) and fake orders. Stricter regulation is needed to regulate the partnership relationship so that drivers can get their rights properly.

\section{REFERENCES}

[1] Wilson, B. (2000). Typescript of short story Brothers and Sisters by Budge Wilson. Budge Wilson fonds (MS-2-650.2013-070, Box 3, Folder 9). Dalhousie University Archives, Halifax, Nova Scotia, Canada. Berliner, R., \& Tal, G. (2018). What drives Your Drivers: An In-depth look at Lyft and Uber Drivers.

[2] Birkinshaw, J., Brannen, M. Y., \& Tung, R. L. (2011). From a distance and generalizable to up close and grounded: Reclaiming a place for qualitative methods in international business research. Springer.

[3] Brito, J. (2014). Agency Threats and the Rule of the Law: An Offer You Can't Refuse. Harv. JL \& Pub. Pol'y, 37, 553.

[4] Burawoy, M. (1985). The politics of production: Factory regimes under capitalism and socialism. Verso Books.

[5] Dyah, M. (2019). How do government regulations and policies respond to the growing online-enabled transportation service (OETS) in Indonesia, the Philippines, and Taiwan? Digital Policy, Regulation and Governance, 21(4), 419-437. https://doi.org/10.1108/DPRG-012019-0001

[6] Eisenhardt, K. M. (1989). Making fast strategic decisions in highvelocity environments. Academy of Management Journal, 32(3), 543576.

[7] Gavin, P. (2017). Regional regulation of transportation network companies. Harv. L. \& Pol'y Rev., 11, 337.

[8] Henao, A., \& Marshall, W. E. (2019). An analysis of the individual economics of ride-hailing drivers. Transportation Research Part A: Policy and Practice, 130, 440-451. https://doi.org/https://doi.org/10.1016/j.tra.2019.09.056

[9] Hidajat, T. (2019). Unethical practices peer-to-peer lending in Indonesia. Journal of Financial Crime, 27(1). https://doi.org/10.1108/JFC-02-2019-0028

[10] Lembaga Demografi UI. (2018). GOJEK Donates IDR 44.2 Trillion to Indonesian Economy.

[11] Mason, S. (2018). High score, low pay: Why the gig economy loves gamification. The Guardian, 20.

[12] Nastiti, A. D. (2017). Worker Unrest and Contentious Labor Practice of Ride-Hailing Services in Indonesia. Arryman Symposium, 1-39.

[13] Nurhidayah, F., \& Alkarim, F. (2017). Domination of Transportation Network Companies (TNCs) in Indonesia: An Indonesian Case. International Journal of Business, Economic and Law, 12(3), 15522289.

[14] Rakhmatulloh, A. R., Tyas, W. P., \& Subianto, M. H. (2018). The Impact of Application-Based Transportation on Labor Absorption in the City of Semarang. JURNAL PEMBANGUNAN WILAYAH \& KOTA, 14(4), 253-264.

[15] Robert, W. (2019). Uberization in Paris - the issue of trust between a 
digital platform and digital workers. Critical Perspectives on International Business, 15(1), 20-41. https://doi.org/10.1108/cpoib-032018-0033

[16] Rosenblat, A., \& Stark, L. (2016). Algorithmic labor and information asymmetries: A case study of Uber's drivers. International Journal of Communication, 10, 27.

[17] Tartelton, G. (2010). The politics of platforms. New Media \& Society, 12(3), 347-364.

[18] Wahyuningtyas, S. Y. (2019). Self-regulation of online platform and competition policy challenges: A case study on Go-Jek. Competition and Regulation in Network Industries, 1783591719834864.

[19] Wyman, K. M. (2017). Taxi regulation in the age of Uber. NYUJ Legis. \& Pub. Pol'y, 20, 1.

[20] Zeng, K. C., Shu, Y., Liu, S., Dou, Y., \& Yang, Y. (2017). A practical GPS location spoofing attack in road navigation scenario. Proceedings of the 18th International Workshop on Mobile Computing Systems and Applications, 85-90. 